\title{
ASPECTOS DA LEI DO DIVÓRCIO
}

O Professor Washington de Barros Monteiro, catedrático de Direito Civil da Faculdade de Direito do Largo de São Francisco, da Universidade de São Paulo, atendendo a um convite do Centro Acadêmico Hugo Simas, por seu Departamento Cultural, pronunciou conferência no salão nobre da Faculdade de Direito da UFPr, abordando o tema "Aspectos da Lei do Divórcio", no dia 24 de junho de 1978.

O acatado mestre paulista, autor de excelente obra de Direito Civil, discorreu sobre os principais aspectos do polêmico instituto recentemente introduzido na legislação brasileira, tendo na oportunidade dialogado com os estudantes a respeito da interpretação a ser dada ao novo diploma legislativo, não escondendo, porém, sua posição doutrinária e filosófica de antidivorcista. 